\title{
English Language Teachers as a Dissenter on a Social Networking Site
}

\author{
Radzuwan Ab Rashid (Corresponding author) \\ Centre of English Language Studies, Faculty of Languages and Communication, Universiti Sultan Zainal Abidin, Gong Badak Campus, Malaysia \\ E-mail: radzuwanrashid@unisza.edu.my \\ Zanirah Wahab \\ Centre of English Language Studies, Faculty of Languages and Communication, Universiti Sultan Zainal Abidin, Gong Badak Campus, Malaysia \\ Kamariah Yunus \\ Centre of English Language Studies, Faculty of Languages and Communication, Universiti Sultan Zainal Abidin, Gong Badak Campus, Malaysia \\ Nur Salina Ismail \\ Centre of English Language Studies, Faculty of Languages and Communication, Universiti Sultan Zainal Abidin, Gong Badak Campus, Malaysia \\ Normah Yusof \\ Centre of English Language Studies, Faculty of Languages and Communication, Universiti Sultan Zainal Abidin, Gong Badak Campus, Malaysia \\ SNM Syed Omar \\ Centre of English Language Studies, Faculty of Languages and Communication, Universiti Sultan Zainal Abidin, Gong Badak Campus, Malaysia \\ Mohd Nazri Latiff Azmi \\ Centre of English Language Studies, Faculty of Languages and Communication, Universiti Sultan Zainal Abidin, Gong Badak Campus, Malaysia \\ Received: 04-02-2016 \\ Published: 01-07-2016 \\ Accepted: 15-04-2016 \\ doi:10.7575/aiac.ijalel.v.5n.4p.72 \\ Advance Access Published: May 2016 \\ URL: http://dx.doi.org/10.7575/aiac.ijalel.v.5n.4p.72
}

\begin{abstract}
This paper explores how teachers discursively construct socially desirable identities to sustain their engagement in the Facebook Timeline community. Data were gathered from the Status updates and Comments on 29 Timelines belonged to Malaysian English language teachers who were purposively chosen as they often posted and commented on teachingrelated issues on their Timelines. The analysis shows that the commonest form of identity construction on the teachers' Timelines was as a dissenter which had been carefully constructed to present positive self-images and cast blames on other people. The teachers questioned the expectations of the people around them, as they perceive that the expectations are unrealistic. This paper concludes that the teachers were being strategic in their postings where they provide justification for their views and ascribe particular identities to other people in the process of constructing their own identity as a dissenter.
\end{abstract}

Keywords: English language teachers, Malaysia, discursive identity, Facebook, dissenter, self-image, self-presentation, discourse analysis

\section{Introduction}

Social networking sites (SNSs) such as Facebook and Twitter have attracted millions of users since their introduction. Nowadays SNSs have been integrated into the users' daily practices. The sites are used for various purposes, such as a platform to engage in informal learning (Rashid and Rahman, 2014; Bilic, 2015), obtaining social support (Rashid, 2016), presenting desirable self-images (Brailovskaia and Bierhoff, 2016), disseminating particular ideologies (Larsson, 2016; Rojecki and Meraz, 2016), creating and maintaining friendship (Buglass et al., 2016) and shopping online (McGuigan and Manzerolle, 2015).

The recent proliferation in use of social networking sites (SNSs) has resulted in new studies examining the role that SNSs play in identity construction (e.g. Zhao, Grasmuck and Martin, 2008; Taylor, Falconer and Snowdon, 2014; Schwartz and Halegoua, 2015; Rashid, 2015). This study aims to expand the previous literature on identity construction on SNSs by providing insights into how English language teachers strategically use the language in their Facebook postings to construct the identity of a dissenter. Previous studies mainly analyse postings in Facebook Groups rather than Timelines and focus on teenagers in general instead of teachers (e.g. Schroeder and Greenbowe, 2009; Wong, Kwan and Leung, 2011). This paper provides novel insights into the identity construction on Facebook afforded by the voluntarily engagement with Status updates and Comments on public Timelines, involving Friends with diverse backgrounds, not engagement in Groups which are private and created by a Group Administrator who usually holds 
authoritative power, and consists of limited members with similar backgrounds, such as a group of first year students studying English courses at University X.

\section{Literature Review}

\subsection{Identity as a discursive construction}

Research on identity has been approached from many perspectives, such as the psychological perspective (e.g. Bruner, 1995; Erikson, 1959), sociolinguistic perspective (e.g. Schriffin, 1996) and educational perspective (e.g. Hammersley, 2002). Benwell and Stokoe's (2006) conceptualization of identity resonates with Gee's (2000) definition of identity as 'being recognized as a certain "kind of person" in a given context' (p.99). Approaching identity from Gee's (ibid) and Benwell and Stokoe's (2006) perspectives acknowledges the fluidity of identity where people have multiple identities depending on how other people in society recognize their actions. Gee (2000) emphasizes the socio-constructionist aspect of discursive identity as not something that one can 'achieve all by oneself' (p.103). It is only because 'other people treat, talk about, and interact' with them that their particular trait, such as being a charismatic teacher is recognized (ibid, p.103). In other words, identity is not an "individual attribute or role but an "emergent feature" of social interactions' (Benwell and Stokoe, 2006, p.50).

Researchers, such as Edwards and Potter (1992), Gee (2000), Bamberg (2003), and Benwell and Stokoe (2006) all agree that discursive identity can be seen as an active accomplishment of individuals or ascribed to individuals. For instance, they may actively recruit charismatic traits by behaving or interacting in a particular way so that other people recognize them as charismatic people, or they might be recognized as being charismatic without any conscious attempts to appear charismatic in front of others. Benwell and Stokoe (2006) point out that the individuals can 'resist' if they do not want to be ascribed a particular identity (p.70). The ascription and accomplishment of identity through discourse are made possible as we 'deliberately or accidentally' reveal and construct 'something of ourselves and who we take ourselves to be' every time we speak (Richards, 2006, p.3). Whilst Richards (2006) points out that discursive construction can be accidental, Gee (2014) emphasizes the deliberateness of the construction process - 'as speakers or writers, we carry out two key jobs' which are 'recipient design' and 'position design' (p.21). Recipient design is adjusting the way of speaking or writing depending on who the recipients are. We speak differently to strangers and friends to indicate our 'social distance' from them (ibid, p.23). Position design is adjusting our way of speaking or writing to 'how we would like our recipients to be, think, feel and behave' thus allowing us to accomplish our desired identities (ibid, p.21).

\subsection{Recent studies on identity in SNS context}

Research on teachers' identities is by no means new. Nonetheless 'little research has been done to understand the relationship between educator identity and participation in SNS' (Kimmons and Veletsianos, 2014, p.8). This section critically reviews three recent studies that do focus on teachers' identity and self-presentation on Facebook: Kimmons and Veletsianos (2014), Olson, Clough and Penning (2009) and Teclehaimanot and Hickman (2011). However, none of these studies analyze how teachers discursively construct their identity through their postings on Facebook, which suggests the need for more studies to explore how teachers engage in discursive identity construction on this particular site.

Kimmons and Veletsianos (2014) employed a grounded theory approach to explore the relationship between educators' Facebook participation and identity. The study involved 18 first-semester teacher-training students from a university in the Southwest of United States. The study participants had attended training in social media professionalism as part of their teacher education program and the data sources consisted of: 1) one-to-one intensive interviews conducted prior to the training in social media professionalism; 2) peer focus groups conducted following the training; and 3) one-to-one follow-up interviews conducted one to two months after the focus groups. Kimmons and Veletsianos found that the fragments of identities perceived to be acceptable to all individuals within a particular context shrink 'as participants connect with individuals from multiple social groups in a single context' (p.296). In other words, when individuals connect with Friends from various backgrounds on Facebook (e.g. close friends, acquaintance, ex-students, and colleagues), the aspects of themselves that they believe to be acceptable to these multiple audiences become more limited compared to when they connect only with a particular social group (e.g. ex-students). Based on this finding, Kimmons and Veletsianos propose a substantive theory that they refer to as the 'Acceptable Identity Fragment' (AIF). A 'substantive theory evolves from the study of a phenomenon situated in one particular situational context' and this contrasts with the 'formal theory [that] emerges from a study of a phenomenon examined under many different types of situation (Strauss and Corbin, 1990, p.174).

Kimmons and Veletsianos (2014) suggest that the AIF is intentional, that it 'does not represent an indiscriminate snapshot of the participants' authentic identities but is akin to a carefully constructed portrait, intended to convey a specific message' to the audiences (p.296). AIF is also authentic, despite being 'an intentional construct', it is 'true to and reflective of [the participants'] authentic identities' where they 'do not feel that they are acting like a different person but are presenting a favorable snapshot of their perceived selves' (ibid, p.296). Besides being intentional and authentic, AIF is also transitional; aspects of selves perceived to be acceptable shift 'over time to remain relevant' to individuals' developing identities (ibid, p.297). In addition, AIF is socially constructed and responsive in that it 'reflects their recognition and perception of others in the context' (p.298). For instance, the participants felt that they had to be 'more careful and secretive' than previously after befriending some professionals on Facebook.

Kimmons and Veletsianos (2014, p.299) attempted to draw a line between their AIF theory and Goffman's (1959) self- 
presentation theory by pointing out that identity in Goffman's dramaturgical view is not necessarily authentic, that people can 'act' or 'play a part' when they use SNS. This is based on Goffman's dramaturgical view of identity in selfpresentation theory: 'when an individual appears in the presence of others, there will usually be some reason for him to mobilize his activity so that it will convey an impression to others which it is in his interests to convey' (Goffman, 1959, p.5). However, I argue that these two theories overlap with each other in part because the mobilizing activity to reveal particular aspects of the self to the audience is not the same as making up an inauthentic identity, but reflects individual agency in constructing their identity at that particular time. Other overlapping points concern the underlying motive(s) behind the constructed identities, engagement in selective self-presentation and the notion that identity is dependent upon social contexts. Notwithstanding, AIF theory is particularly useful in drawing attention to identity construction in 'multiple social groups in a single context' (Kimmons and Veletsianos, 2014, p.296) as offered by SNS, such as Facebook.

Olson et al. (2009) examined 358 publicly accessible Facebook profiles of pre-service teachers majoring in elementary education at a large public Midwestern university in order to explore how they portrayed themselves in their postings. The researchers categorized the postings into three types: appropriate (not likely to offend parents and administrators); marginal (possibly offensive to those stakeholders but probably acceptable to others); and inappropriate (offensive to the researchers and potentially to parents and administrators). They found that 56 per cent of the profiles contained inappropriate postings, such as 'I get paid to watch your kids, be afraid, be very afraid.' (p.452). A total of 78 per cent of the profiles contained both marginal and inappropriate categories of postings 'that could prevent an elementary education major from being allowed to work with children' (p.456). These findings suggest that teachers may post things considered inappropriate by higher authorities on their Timelines. However, all the participants in Olson et al.'s study were in their first year of teacher training thus the findings are not transferrable to the context of this study, which involves in-service teachers who may craft their postings more carefully than pre-service teachers.

Teclehaimanot and Hickman (2011) distributed a survey instrument to 52 students in the College of Education at the University of Toledo, and they concluded that only certain aspects of teachers' behaviour are perceived by students to be acceptable on Facebook. Even though the participants consisted of pre-service and in-service teachers, they were instructed to respond solely from the perspective of higher education students. This study revealed that students in general perceive teachers' passive behaviour (e.g. viewing and reading students' Profiles) as more acceptable than active behaviour (e.g. posting and commenting). Nonetheless, this perception varies across genders, in that male students are more accepting of teachers' active behaviour than female students.

Kimmons and Veletsianos' (2014) findings, those of Olson et al. (2009) and Teclehaimanot and Hickman (2011) highlighted in this sub-section raise the issue of teachers' socially-acceptable identities on SNS. It is important for teachers to be careful and regulate their behaviour on the site and only construct socially-acceptable identities so that they do not jeopardize their professional status.

\section{Methodology}

This study employed a broadly ethnographic qualitative approach and closely focused on the participants' unfolding discourse as they interact on Timelines. To some extent, the ethnographic approach employed in this study can be associated with 'linguistic ethnography' (Wetherell, 2007; Copland and Creese, 2015) since it closely focuses on the discursive behaviour of the participants. As highlighted by Wetherell (2007), linguistic ethnography 'brings together [linguistic and ethnographic approaches], in the same analytic space [to] study the discursive patterns found in everyday interactions and aims to situate these in the dynamics of wider cultural settings' (p.661).

In generating data for this study, I recorded 178 teaching-related Status updates on the Timelines, together with the 1226 Comments that these had attracted. The Status updates and Comments were posted by 29 English language teachers teaching in secondary schools across the country. They were purposively chosen as they often posted and commented on teaching-related issues on their Timelines. Detailed discussion on the ethical and methodological issues that arose in this study has been presented in a paper published by The Nottingham Jubilee Press (see Rashid, 2014).

Two different forms of discursive analytical approach are employed in this study: discourse analysis in its broadest sense and discursive psychology. I use the term 'discourse analysis in its broadest sense' or 'broad discourse analysis' to differentiate it from Foucauldian discourse analysis and critical discourse analysis, which are two recent conceptualizations of discourse. As Atkinson, Okada and Talmy (2011) point out, Foucauldian discourse analysis originates from neo-Marxist understandings of social inequality, hence focuses on how language functions to maintain and foster such inequality, whereas critical discourse analysis, which is associated with Fairclough (1995), examines how social group members reproduce or resist power, dominance and inequality through text and talk. Since inequality, power and dominance are not the primary constructs being studied in this research, Foucauldian discourse analysis and critical discourse analysis were deemed inappropriate.

Broad discourse analysis provides a framework for understanding general communicative behaviour within which syntax, semantics and pragmatics can be situated (Miller, 2004). When analysing the Status updates and Comments using this broad discourse analysis approach, I focused on traditional theoretical linguistics, such as choice of syntactic construction, choice and structure of referring expression/noun phrases, choice of tense and aspect and choice of word order.

Edwards and Potter's (1992) discursive psychology is also employed as an analytical approach in this study, especially in examining how teachers construct their desired identities through the Status updates and Comments on their 
Timelines. As pointed out by Edwards and Potter, identity is one of the psychological themes in addition to motives, attitudes, and morals that underpin conversations and interactions. The underlying principle of discursive psychology is that texts and talks are oriented towards action (Edwards and Potter, 1992; Edwards, 2005; Te Molder and Potter, 2005); that is, talk is not merely a reflection of mental events, but a means to achieve goals in a socially meaningful world. Employing discursive psychology enabled me to explore how identities are handled and managed in discourse by focusing on the elements suggested by Edwards and Potter (2005), such as those involving blame, justification and defence.

\section{Analysis and Discussion}

The identity of a dissenter is mainly salient when the teachers show dissatisfaction and disagreement with the views and expectations of the people around them. This section scrutinizes four examples of Status updates which show that teachers construct the identity of a dissenter using various discursive strategies. Two of the Status updates are used to express disagreement with the policy makers and the other two Status updates express disagreement with colleagues.

Extract 1 represents a Status update taken from Barnett's Timeline where she introduced the topic by challenging the opinion of a policy maker regarding the possible causes of students' poor proficiency in the English language. The opinion of the policy maker was published in a local newspaper, NST (line 1) i.e. New Straits Times.

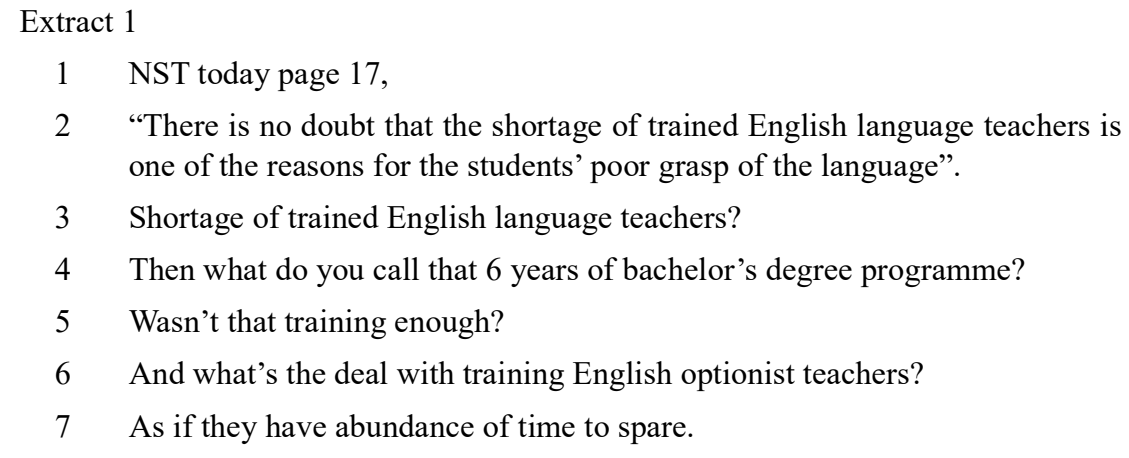

(Barnet/SU2)

Barnett chooses to use NST as the subject, the center of attention in this Status update. By doing this, Barnett presents herself as someone who is brave enough to challenge the published opinions that have been reviewed by an editor. In line 2, Barnett uses 'intertextuality' (Gee, 2014) that is, using 'words other people have said or written' (p.49) where she quotes the sentence she disagrees with to show that she has not changed a single word of opinion expressed, thus engaging in Edwards' (2005) factual description strategy. Following this quotation, Barnett poses four rhetorical questions (lines 3-6) embedded with facts about teachers' training to challenge the policy maker's opinion and justify her disagreement. Questioning other people's opinions is a technique used by Barnett to deconstruct the opinion expressed and point out the weaknesses in the argument. It is clear that the questions are directly addressed at the policy maker from the pronoun you used in line 4. The use of you here suggests that Barnett 'notes the social involvement' of the policy maker 'as a listener' (Gee, 2014, p.65). However, we know that Barnett does not say this in front of the policy maker, thus she can be said to engage in the construction of 'dialogue representing what wasn't said' (Tannen, 1989, p.111) to allow this Status update to become dynamic. It is important to make this Status update appear active so that readers are interested in taking up the topic.

Barnett ends the Status update with the comment as if they have abundance of time to spare (line 7) reflecting her belief that English language teachers have been busy enough attending training courses to be considered trained teachers. She uses the pronoun they as the 'footing' (Goffman, 1981, p.128) rather than we, so distancing herself from this argument, hence avoiding the risk of being seen as fighting only for her personal interests, and creating the effect that her argument is for all the English language teachers out there.

Extract 2 is another example of a Status update used by the teachers to construct the identity of a dissenter. It is taken from Wafi's Timeline where she introduces the topic by challenging the view of the policy makers who thought that importing English language teachers from India would help to improve Malaysian students' proficiency.

\section{Extract 2}

$1 \quad$ Nak bawak masuk guru BI dari India?? (English: Want to bring in English language teachers from India??)

2 Macam2 la. (English: What bollocks.)

3 We have adequate and qualified teaching personnels over here.

4 Why do we need to rely on the service of others and disregard the sacrifices the local teachers made?

\section{(Wafi/SU1)}

Wafi starts this Status update by posing a question with double question marks (line 1), which reflects her surprise at the government's decision to import English language teachers from India. The use of the double question marks to show surprise resonates with Gee (2014), who suggests that language can be used 'to render something as significant or to 
lessen their significance, or to signal to others how we view their significance' (p.32). Here, Wafi tried to show that this new policy is significant to her as she is an English language teacher thus justifying her decision to talk about this topic. The Malay language used in the question can be seen as 'a spoken sign in a written voice' (Bakker and Kahane, 2009) as if she is having a spoken conversation which does not allow her to 'buy [much] time' (Thornbury and Slade, 2006, p.57), not enough to formulate the question in English. This immediacy, according to Georgakopoulou and Finnis (2009), creates the impact that the news to be shared is very up to date and newsworthy.

Wafi then writes what bollocks (line 2) which indicates her rejection of this idea. After making her stance clear, that she disagrees with this idea, Wafi puts forth her argument that there are adequately qualified teachers in Malaysia already (line 3). She uses two adjectives adequate and qualified to describe Malaysian teachers and emphasize that Malaysia is not in need of English language teachers from India. In lines 3 and 4, we is used as the 'footing' (Goffman, 1981, p.128) which shows that Wafi does not distance herself from this argument and it reflects her views as belonging to the group who should have a say about the operation of the Malaysian education system.

Similar to Barnett in a previous Status update, Wafi uses a questioning technique to deconstruct the views that she does not agree with and point out the weaknesses in them. This is visible in her last line where she poses a thought-provoking question Why do we need to rely on the service of others and disregard the sacrifices the local teachers made? (line 4). The phrase rely on the service of others, has negative connotations, emphasizing her stance that Malaysia should not import teachers from India. She also uses the word sacrifices to describe what Malaysian teachers have done, which implies that the teachers have prioritized the country's needs over their personal needs and therefore they deserve to get any teaching jobs in their country.

Extract 3 is an example of a Status update used to construct the identity of a dissenter by showing disagreement with colleagues' views, hence resulting in problematic relationships with colleagues. This Status update is taken from Eisya's Timeline. Eisya introduces the topic by expressing disagreement with the advice that she needs to be a loving teacher to successfully manage students with unruly behavior.

\section{Extract 3}

1 Yeah sure, I lurvveee my students.

2 But if you expect me to wait at the gate

3 and say "Bonda gembira anakanda datang ke sekolah hari ini", (English: "Mom is happy that you kids come to school today")

4 You'll be disappointed.

5 Moreover, I believe that "Spare the rod and spoil the child"

(Eisya/SU1)

Eisya begins her Status update with an ironic statement about her attitude to her students (line 1). The fact that she begins with yeah, sure and then spells the word love as lurvveee adds an attitude of sarcasm. The way she spells love resonates with Gee's (2014) notion of 'vernacular language', that is, the language 'used when we want to talk as an "everyday person" not as a specialist of any kind' (p.8). She then points out her disagreement with the advice to approach students as a loving teacher when she writes that waiting at the gate and saying she is pleased the children came to school (lines 2-3) is not her style and her adviser will be disappointed (line 4). The constructed dialogue here is a 'dialogue representing what wasn't said' (Tannen, 1989, p.111) as Eisya does not utter these words in front of her colleague and she also implies that she will not say this to her students (line 4). Eisya uses the word Bonda (English: Mother) and anakanda (English: children) to exaggerate the politeness required when talking to the students. The word Bonda is used by the queen to refer to herself when talking to her anakanda or children. This exaggeration creates a very sarcastic sentence, hence reflecting her disagreement with the idea of the loving teacher proposed by her colleague. Exaggeration is an example of 'embellishment or decoration' by the storyteller to make a story more 'entertaining' (Carter and McCarthy, 1997, p.23). Even though this Status update does not fit the storytelling genre, there are elements of storytelling that make it exciting, such as the use of constructed dialogues and exaggeration, thus encouraging Friends to continue the topic.

After sarcastically commenting on the colleague's belief, Eisya puts forward her own belief that students should be punished if they do something wrong so that they will learn from their mistakes, shown in spare the rod and spoil the child (line 5). Interestingly, Eisya uses an idiom to summarize her belief, which contradicts her colleague's belief. The use of idiom makes her belief sound much more credible than her colleague's belief as it is an old saying well understood by the community.

Extract 4 shows how Zeti constructs the identity of a dissenter by presenting herself as having an opinion in conflict with that of the senior teachers in her school. Zeti introduces the topic by expressing her dissatisfaction with the senior teachers who she perceives as being fussy about the seating arrangements for a dinner party.

\section{Extract 4}

$1 \quad$ Ak $x$ fhm dgn prngai org seasoned kt skola ak ni. (English: I don't understand the attitude of seasoned teachers in my school) 
$2 \quad$ Nk g dinner pun satu masalah besar nk susun meja. (English: Even going to dinner is a big problem to arrange table)

3 Just go to the fuckin dinner $n$ fuckin eat

$4 \mathrm{n}$ don't make it such a fuckin problem,

$5 \quad$ can $\mathrm{u}$ do that for once in your life?

(Zeti/SU2)

Zeti highlights her inability to understand the attitude of senior teachers at her school (line 1), which implies that there is a conflict of views between her and the senior teachers. She describes the teachers as seasoned teachers to show that they are older than her, hence that they are supposed to act sensibly. However, she describes these seasoned teachers as very fussy about the organisation of a school dinner they are to attend, particularly about the seating arrangements. Ascribing certain characteristics to other people is a form of discursive psychology to allow individuals to accomplish their desired identity (Bamberg, 2003, 2011). For instance, by describing the seasoned teachers as very fussy, Zeti implies that she is less fussy than they are. She holds the opinion that they should not care so much about the seating arrangements, expressed when she demands the seasoned teachers just go to the fuckin dinner $n$ fuckin eat $n$ don't make it a fuckin problem (lines 3-4). She repeats the word fuckin three times, which indicates her annoyance with the seasoned teachers. To justify her feelings of annoyance with the teachers, Zeti then poses a rhetorical question, can $u$ do that for once in your life? (line 5) which suggests that these teachers have always been fussy about many things, and hence it is not her fault that she feels annoyed with the teachers, given that they have this fussy attitude when they should act more maturely due to their seniority.

\section{Conclusion}

The teachers construct the identity of a dissenter mainly through questioning the expectations of the people around them, as they perceive that their expectations are unrealistic. They also employ discursive psychology strategies, such as providing justification for their views and ascribing particular identities to other people in the process of constructing their own identity as a dissenter. Highlighting unhelpful behaviour enables their Friends to realize that teachers live a stressful professional life, hence encouraging them to continue the topic by giving supportive responses to the teachers. It is interesting that even though the Status updates used to construct the identity of a dissenter do not fit into the storytelling genre, they contain some elements of storytelling, such as constructed dialogues, exaggeration, and immediacy to make the Status updates interesting to readers, thus encouraging them to take up the topic.

\section{References}

Atkinson, D., Okada, H., \& Talmy, S. (2011). Discourse analysis and ethnography. In K. Hyland \& B. Paltridge (Eds.), Continuum companion to discourse analysis (pp.85-100). London, UK: Continuum.

Bakker, E., \& Kahane, A. (2009). Written voices spoken signs. Cambridge, MA: Havard University Press.

Bamberg, M. (2003) Stories, tellings, and identities. In C. Daiute \& C. Lightfoot (Eds.), Narrative analysis: Studying the development of individuals in society (pp.135-157). London, UK: Sage.

Bamberg, M. (2011). Who am I? Narration and its contribution to self and identity. Theory \& Psychology, 21(1), 3-24. http://dx.doi.org/10.1177/0959354309355852

Benwell, B., \& Stokoe, E. (2006). Discourse and identity. Edinburgh, UK: Edinburgh University Press.

Bilic, P. (2015). 'Searching for a centre that holds' in the network society: Social construction of knowledge on, and with, English Wikipedia. New Media \& Society, 17, 1258-1276.

Brailovskaia, J., \& Bierhoff, H. (2016). Cross-cultural narcissism on Facebook: Relationship between self-presentation, social interaction and the open and covert narcissism on a social networking site in Germany and Russia. Computers in Human Behaviour, 55, 251-257.

Bruner, J. (1995). The autobiographical process. Current Sociology, 43(2), 161-177. http://dx.doi.org/10.1177/001139295043002015

Buglass, S.L., Binder, J.F., Betts, L.R., \& Underwood, J.D.M. (2016). When 'friends' collide: Social heterogeneity and user vulnerability on social network sites. Computers in Human Behaviour, 54, 62-72.

Carter, R., \& McCarthy, M. (1997). Exploring spoken English. Cambridge, UK: Cambridge University Press.

Copland, F., \& Creese, A. (2015). Linguistic ethnography: Collecting, analysing and presenting data. London, UK: Sage.

Edwards, D. (2005). Discursive psychology. In K.L. Fitch \& R.E. Sanders (Eds.), Handbook of language and social interaction, (pp. 257-273). London, UK: Erlbaum.

Edwards, D., \& Potter, J. (1992) Discursive psychology. London: Sage.

Edwards, D., \& Potter, J. (2005). Discursive psychology, mental states and descriptions. In H. Te Molder \& J. Potter (Eds.), Conversation and cognition, (pp.241-259). Cambridge, UK: Cambridge University Press.

Erikson, E.H. (1959). Identity and the life cycle: selected papers. Psychological Issues 1, 1-171.

Fairclough, N. (1995). Critical discourse analysis: The critical study of language. London, UK: Longman 
Gee, J.P. (2000). Identity as an analytic lens for research in education. Review of Research in Education, 25(1), 99-125. http://dx.doi.org/10.3102/0091732X025001099

Gee, J.P. (2014). An introduction to discourse analysis: Theory and method (4 ${ }^{\text {th }}$ ed.). London, UK: Routledge.

Georgakopoulou, A., \& Finnis, K. (2009). Code-switching 'in site' for fantasizing identities: A case study of conventional uses of London Greek Cypriot. Pragmatics, 19(3), 467-488. Retrieved from http://elanguage.net/journals/pragmatics/article/view/1386/944

Goffman, E. (1959). The presentation of self in everyday life. New York, US: Doubleday.

Goffman, E. (1981). Forms of talk. Philadelphia, US: University of Pennsylvania.

Hammersley, M. (2002). Educational research, policymaking and practice. London, UK: Paul Chapman.

Kimmons, R., \& Veletsianos, G. (2014). The fragmented educator 2.0: social networking sites, acceptable identity fragments, and the identity constellation. Computers and Education, 72, 292-301. http://dx.doi.org/10.1016/j.compedu.2013.12.001

Larsson, A.O. (2016). Online, all the time? A quantitative assessment of the permanent campaign on Facebook. New Media \& Society, 18(2), 274-292.

McGuigan, L., \& Manzerolle, V. (2015). “All the world's a shopping cart": Theorizing the political economy of ubiquitous media and markets. New Media \& Society, 17, 1830-1848.

Miller, J. (2004). Discourse analysis. Centre for Languages, Linguistic and Area Studies, University of Southampton. Retrieved from https://www.llas.ac.uk/resources/gpg/132

Olson, J., Clough, M., \& Penning, K. (2009). Prospective elementary teachers gone wild? An analysis of Facebook selfportrayals and expected dispositions of preservice elementary teachers. Contemporary Issues in Technology and Teacher Education 9, 443-475.

Richards, K. (2006). Language and professional identity: aspects of collaborative interaction. Basingstoke, UK: Palgrave Macmillan.

Rashid, R. A. (2015). Religion-related discourse in an apostate's social networking site account, $1^{\text {st }}$ World Islamic Social Science Congress, Putrajaya, Malaysia.

Rashid, R.A. (2016). Topic continuation strategies employed by teachers in managing supportive conversations on Facebook Timeline. Discourse Studies, 18(2), 188-203. http://dx.doi.org/10.1177/1461445615623906

Rashid, R.A., \& Rahman, M.F. (2014). Social networking sites for online mentoring and creativity enhancement. International Journal of Technology Enhanced Learning 6(1), 34-45. http://dx.doi.org/10.1504/IJTEL.2014.060024

Rashid, R.A. (2014). Exploring methodological and ethical issues in researching teachers' informal learning on a social networking site. Nottingham: The Nottingham Jubilee Press.

Rojecki, A., \& Meraz, S. (2016). Rumors and factitious informational blends: The role of the web in speculative politics. New Media \& Society, 18(1), 25-43.

Schriffin, D. (1996). Narrative as a self-portrait: sociolinguistic constructions of identity. Cambridge, UK: Cambridge University Press.

Schroeder, J., \& Greenbowe, T.J. (2009). The chemistry of Facebook: using social networking to create an online community for the organic chemistry laboratory. Innovate 5(4).

Schwartz, R., \& Halegoua, G.R. (2015). The spatial self: Location-based identity performance on social media. New Media and Society, 17 (10), 1643-1660.

Strauss, A., \& Corbin, J. (1990). Basics of qualitative research: Grounded theory procedures and techniques. Newbury Park, CA: Sage.

Taylor, Y., Falconer, E., \& Snowdon, R. (2014). Queer youth, Facebook and faith: Facebook methodologies and online identities. New Media \& Society, 16(7), 1138-1153.

Tannen, D. (1989). Talking voices. Cambridge, UK: Cambridge University Press.

Teclehaimanot, B.B., \& Hickman, T. (2011). Student-teacher interaction on Facebook: what students find appropriate. TechTrends, 55(3), 19-30. http://dx.doi.org/10.1007/s11528-011-0494-8

Te Molder, H., \& Potter, J. (2005). Conversation and cognition. Cambridge, UK: Cambridge University Press.

Thornbury, S., \& Slade, D. (2006). Conversation: from description to pedagogy. Cambridge, UK: Cambridge University Press.

Wetherell, M. (2007). A step too far: discursive psychology, linguistic ethnography and questions of identity. Journal of Sociolinguistics, 11(5), 661-681. http://dx.doi.org/10.1111/j.1467-9841.2007.00345.x

Wong, K., Kwan, R., \& Leung, K. (2011). An exploration of using Facebook to build a virtual community of practice. $4^{\text {th }}$ ICHL conference proceedings [online]. Retrieved from http://link.springer.com/chapter/10.1007\%2F978-3-64222763-9_30

Zhao, S., Grasmuck, S., \& Martin, J. (2008) Identity construction on Facebook: Digital empowerment in anchored relationships. Computers in Human Behavior, 24(5), 1816-1836. 